\title{
Otimização de metodologia para 0 estudo de genes KIR
}

\author{
Methodology optimization for KIR genotyping
}

Cristiane Conceição Chagas Rudnick; Gláucia Andréia Soares Guelsin²; Amanda Vansan Marangon³; Danilo Santana Alessio Franceschi ${ }^{4}$; Ana Maria Sell ${ }^{5}$; Jeane Eliete Laguila Visentainer ${ }^{6}$

\begin{abstract}
unitermos
Células natural killer

resumo

Genotipagem

Receptores killer cell immunoglobulin-like (KIRs) são moléculas localizadas na superfície de células natural killer (NK) e em subpopulações de linfócitos T codificadas por genes do cromossomo 19q13.4. A interação entre receptores KIR e moléculas antígeno leucocitário humano (HLA) de classe I determina KIR se células NK exercerão ou não sua função citotóxica e/ou secretora de citocinas ou se esta será inibida.

PCR-SSP Este trabalho teve por finalidade otimizar a metodologia para a genotipagem KIR, baseando-se nas condições descritas por Martin (2004). A técnica utilizada foi a reação em cadeia da polimerase com primers de sequência específica (PCR-SSP) com iniciadores sintetizados pela Invitrogen ${ }^{\circledR}$ e visualização do produto amplificado em gel de agarose a $2 \%$ com brometo de etídio. Adaptações foram realizadas e a concentração de alguns reagentes foi alterada, como a do controle interno de $100 \mathrm{nM}$ para $150 \mathrm{nM}$, iniciadores específicos senso e antissenso de KIR12.5/12.3, KIR13.5/13.3, KIR14.5/14.3, KIR22.5/22.3 e KIR36.5/36.3 de $500 \mathrm{nM}$ para $750 \mathrm{nM}$ e da solução de $\mathrm{MgCl}_{2}$ de 1,5 mM para $2 \mathrm{mM}$. As concentrações dos demais reagentes e temperaturas de amplificação foram mantidas. Nessas condições, o uso da Taq DNA polimerase recombinante (Invitrogen ${ }^{\circledR}$ ) foi satisfatório. Os resultados das genotipagens de 70 indivíduos foram confirmados por rSSO-Luminex ${ }^{\circledR}$ (One Lambda, Canoga Park, CA, EUA). A tipagem de genes KIR por essa técnica apresentou sensibilidade, especificidade, reprodutibilidade e baixo custo.
\end{abstract}

\section{abstract}

The killer cell immunoglobulin-like receptors (KIRs) are molecules expressed on natural killer (NK) cells surface and in T-cell subsets encoded by genes located in chromosome 19q13.4. The interaction between KIR receptors and HLA class I molecules determines if the NK cells will fulfill their cytotoxic function and/or cytokine secretion or if this function will be inhibited. The objective of this work was to optimize KIR genotyping method described by Martin (2004). It was used PCR-SSP (polymerase chain reaction-sequence-specific primers) with primers synthesized by Invitrogen ${ }^{\circledast}$ and visualization of the amplified products on $2 \%$ agarose gel electrophoresis, containing ethidium bromide. Some adaptations were made and the reagents had their concentrations increased: the internal control from $100 \mathrm{nM}$ to $150 \mathrm{nM}$, forward and reverse specific primers KIR12.5/12.3, KIR13.5/13.3, KIR14.5/14.3, KIR22.5/22.3 and KIR36.5/36.3 from $500 \mathrm{nM}$ to $750 \mathrm{nM}$, and $\mathrm{MgCl}_{2}$ solution from $1.5 \mathrm{mM}$ to $2 \mathrm{mM}$. Other reagent concentrations and amplification temperatures were maintained. Satisfactory results were obtained with Taq DNA Polymerase Recombinant (Invitrogen $\left.{ }^{\circledR}\right)$. The results of seventy samples were confirmed by rSSO-Luminex ${ }^{\circledast}$ (One Lambda, Canoga Park, CA, USA). This KIR typing method proved to be accurate, specific, reproducible and cost effective. key words

Natural killer cells

Genotyping

KIR

PCR-SSP

PCR-SSO

1. Acadêmica de pós-graduação em Análises Clínicas da Universidade Estadual de Maringá (UEM).

2. Acadêmica de graduação do curso de Farmácia, Departamento de Análises Clínicas, da UEM.

3. Acadêmica de graduação do curso de Farmácia, Departamento de Análises Clínicas, da UEM.

4. Acadêmico de pós-graduação em Análises Clínicas da UEM.

5. Doutora do Departamento de Ciências Básicas da Saúde, Laboratório de Imunogenética, da UEM.

6. Doutora do Departamento de Ciências Básicas da Saúde, Laboratório de Imunogenética, da UEM. 


\section{Introdução}

As células natural killer (NK) desempenham importante papel na resposta imune inata, pois são responsáveis pela lise de células infectadas por vírus( ${ }^{(4)}$, células tumorais ${ }^{(2,22,23,58)} \mathrm{e}$ células alogênicas ${ }^{(6)}$, como também secretam citocinas como interferon-gama (IFN- $\gamma$ ), fator de necrose tumoral (TNF) e fator estimulador de colônia granulócito-macrófago (GM$\mathrm{CSF})^{(4)}$. Possuem vários tipos de receptores em sua superfície, entre os quais receptores killer cell immunoglobulin-like (KIR), glicoproteínas pertencentes à superfamília das imunoglobulinas que têm como ligantes moléculas de antígeno leucocitário humano (HLA) de classe ${ }^{(31)}$. Na ausência ou na expressão reduzida de moléculas HLA de classe I em célulasalvo, estas são destruídas pelas células $\mathrm{NK}^{(29)}$. Os receptores KIR podem ser de ativação e de inibição e, para que as células NK consigam distinguir alvos desprovidos ou não de moléculas HLA de classe I, é necessária a ligação simultânea nestes receptores ${ }^{(31)}$. Os sinais de inibição predominam sobre os de ativação, prevenindo, assim, a lise de células autólogas normais ${ }^{(39)}$. A diversidade KIR está relacionada com a variabilidade no número de genes, no tipo de genes, de seus alelos e haplótipos ${ }^{(24,50,53)}$,e o polimorfismo KIR em humanos pode estar relacionado com a seleção natural exercida por patógenos ${ }^{(50)}$.

Os receptores KIR são codificados por genes do complexo de receptores leucocitários (LRC), situados no cromossomo $19 \mathrm{q} 13.4^{(56)}$. Atualmente, 15 genes e dois pseudogenes KIR foram identificados ${ }^{(17,19,35)}$ : KIR2DL1, KIR2DL2, KIR2DL3, KIR2DL4, KIR2DL5A, KIR2DL5B, KIR2DS1, KIR2DS2, KIR2DS3, KIR2DS4, KIR2DS5, KIR3DL1, KIR3DL2, KIR3DL3, KIR3DS1, KIR2DP1 e KIR3DP1. Até janeiro de 2009, foram descritos 335 alelos distribuídos nos diferentes locus ${ }^{(25)}$. A importância da tipagem de genes KIR está relacionada com o conhecimento da diversidade desses genes em diferentes indivíduos e, consequentemente, em diferentes populações $(1,5,7,10,11,13,14,16,18,21,27,33,34,38,42,43,45-47,49,52,57,54,55,59)$, ao papel exercido por esses receptores na resposta imune inata, sua relação com a predisposição ou com a resistência ao desenvolvimento de doenças virais, autoimunes e tumorais $^{(3,15,26,28,30,32,36)}$ e, ainda, à influência desse polimorfismo nos transplantes de medula óssea alogênicos ${ }^{(48)}$.

Os métodos utilizados para detectar a presença ou ausência de genes KIR se baseiam em técnicas de biologia molecular: reação em cadeia da polimerase com transcrição reversa (RT-PCR) ${ }^{(53)}$, reação em cadeia da polimerase

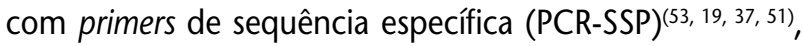
reação em cadeia da polimerase com oligonucleotídeos de sequência específica (PCR-SSOP) ${ }^{(9)}$ e, mais recentemente, a técnica oligonucleotídeos de seqüência específica reversa rSSO com tecnologia Luminex ${ }^{\circledR}$ para tipagem dos genes e alelos $\mathrm{KIR}^{(41)}$. A técnica PCR-SSP descrita por Martin ${ }^{(37)}$ permite a análise de 14 genes e um pseudogene KIR a um custo não elevado, pois utiliza pouca quantidade de reagentes, muitos dos quais podem ser preparados no laboratório, e os iniciadores podem ser confeccionados a partir de sequências de bases predefinidas. Nesta técnica, a concentração de DNA deve ser de $10 \mathrm{ng}$ e o volume final de reação, de $10 \mu$, recomendando-se o uso de Platinum Taq DNA Polimerase (Invitrogen ${ }^{\circledR}$ ).

O objetivo do presente estudo foi a otimização da técnica de PCR-SSP, descrita por Martin, tendo em vista a necessidade de métodos que apresentem sensibilidade, especificidade, fácil execução e interpretação, baixo custo e que não exijam equipamentos sofisticados.

\section{Materiais e métodos}

O estudo foi conduzido de acordo com as normas preconizadas pelo Comitê de Ética em Pesquisa com Seres Humanos da Universidade Estadual de Maringá (COPEP-UEM), conforme Parecer 272/2004.

Cinco mililitros de sangue total de 70 indivíduos não relacionados e selecionados aleatoriamente foram coletados em tubos contendo (EDTA). As amostras foram obtidas de forma a abranger os genótipos KIR representativos da população brasileira(47). O sangue foi centrifugado para obtenção de uma camada rica em células nucleadas (creme leucocitário), a qual foi congelada em tubos de criopreservação até o momento da extração do DNA.

\section{Extração de DNA}

A extração de DNA foi realizada pelo kit EZ-DNA (Biological Industries ${ }^{\mathrm{TM}}$, Beit Haemek, Israel), de acordo com o protocolo do fabricante, a partir de $150 \mu$ do creme leucocitário. O DNA foi reidratado com água de injeção e a concentração de DNA foi determinada no fluorômetro Qubit $^{\text {TM }}$ (Invitrogen ${ }^{\circledR}$, Carlsbad, CA, EUA).

\section{Genotipagem KIR}

Para a genotipagem KIR foi utilizada a técnica PCR-SSP, descrita por Martin ${ }^{(37)}$, com modificações para a tipagem de 14 genes e um pseudogene: KIR2DL1, KIR2DL2, KIR2DL3, KIR2DL4, KIR2DL5, KIR2DS1, KIR2DS2, KIR2DS3, KIR2DS4, 
KIR2DS5, KIR3DL1, KIR3DL2, KIR3DL3, KIR3DS1 e KIR2DP1. Para o desenvolvimento desta técnica foram utilizados iniciadores confeccionados pela Invitrogen (Invitrogen ${ }^{\circledR}$, Carlsbad, CA, EUA).

De acordo com o procedimento padrão elaborado por Martin ${ }^{(37)}$, a mistura da PCR foi preparada para o volume final de reação igual a $10 \mu$; tampão PCR 10X - 200 mM Tris- $\mathrm{HCl}(\mathrm{pH} 8,4), 500 \mathrm{mM} \mathrm{KCl} ; 1,5 \mathrm{mM}$ de $\mathrm{MgCl}_{2 ;} 200 \mu \mathrm{M}$ de cada dNTP; $100 \mathrm{nM}$ de iniciadores $5^{\prime}$ e $3^{\prime}$ do controle interno; $500 \mathrm{nM}$ de iniciadores específicos; 0,25 unidade de Platinum Taq DNA Polimerase (Invitrogen ${ }^{\circledR}$, Carlsbad, $(\mathrm{CA}, \mathrm{EA}), 10 \mathrm{ng}$ de DNA e água destilada estéril suficiente para completar o volume.

De início, a reação foi preparada com todos os reagentes e o DNA, exceto os iniciadores específicos. Essa mistura foi a seguir distribuída em microtubos de volume de $0,2 \mathrm{ml}$ que continham os iniciadores na concentração final de $500 \mathrm{Nm}$ (Tabela 1). A enzima utilizada foi a Platinum Taq DNA Polimerase (Invitrogen ${ }^{\circledR}$, Carlsbad, CA, EUA), recomendada por fornecer melhores resultados, ou a Taq DNA Polimerase Recombinante (Invitrogen ${ }^{\circledR}$, Carlsbad, CA, EUA). As temperaturas e condições de amplificação foram: desnaturação inicial a $94^{\circ} \mathrm{C}$ por 3 minutos, quatro ciclos de $94^{\circ} \mathrm{C}$ por 15 segundos, anelamento a $65^{\circ} \mathrm{C}$ por 15 segundos e extensão a $72^{\circ} \mathrm{C}$ por 30 segundos, 21 ciclos de $94^{\circ} \mathrm{C}$ por 15 segundos, $60^{\circ} \mathrm{C}$ por 15 segundos e $72^{\circ} \mathrm{C}$ por 30 segundos, 5 ciclos de $94^{\circ} \mathrm{C}$ por 15 segundos, $55^{\circ} \mathrm{C}$ por 1 minuto e $72^{\circ} \mathrm{C}$ por 2 minutos e, finalizando, a $72^{\circ} \mathrm{C}$ por 7 minutos. Para as amplificações foram utilizados os termocicladores Perkin Elmer GeneAmp 9600 e Applied Biosystem GeneAmp 9700 (Foster City, CA, EUA). Modificações dessas condições foram realizadas quando necessário.

A visualização do produto amplificado foi realizada em gel de agarose a $2 \%$ com brometo de etídio $(5 \mathrm{~g} / \mathrm{ml})$, contra luz ultravioleta. A visualização e a fotodocumentação foram realizadas no transiluminador BioDoc-It ${ }^{\text {TM }}$ Imaging System (UVP Upland, CA, EUA). O controle interno amplificou um fragmento de $796 \mathrm{pb}$ do terceiro íntron de HLA-DRB1.

\section{Validação do método}

Para validação do método foram utilizados dois kits comerciais: rSSO Luminex ${ }^{\circledast}$ (One Lambda, Canoga Park, CA, EUA) do lote 002 e o kit de genotipagem KIR SSP (DYNAL ${ }^{\circledR}$ Invitrogen Corporation) do lote 003.

O princípio da técnica rSSO Luminex ${ }^{\circledR}$ se baseia primeiramente na amplificação do DNA-alvo por PCR, utilizando três grupos de iniciadores específicos para os éxons 3, 5 e 7-9, em reações separadas. Cada produto de PCR é biotinilado, o que permite a sua detecção pelo conjugado ficoeritrinaestreptavidina (SAPE). Em seguida, cada produto de PCR é desnaturado para ser hibridizado com sondas conjugadas a microesferas fluorescentes codificadas. O DNA hibridizado e ligado às microesferas é marcado com SAPE e a reação é lida no citômetro de fluxo $\mathrm{LABSCan}^{\mathrm{TM}} 100$, que identifica a intensidade de fluorescência da ficoeritrina em cada microesfera.

O kit de genotipagem KIR SSP da Invitrogen ${ }^{\text {TM }}$ é um método baseado na PCR que utiliza sequência específica de iniciadores para a detecção da presença e ausência de genes KIR. O produto da PCR é dispensado em gel de agarose a $2 \%$ com brometo de etídio, seguido de eletroforese e visualização contra luz ultravioleta. Para a interpretação dos resultados utiliza-se uma ficha de interpretação padrão proveniente do fabricante.

\section{Resultados}

\section{Alteração da concentração do controle interno de $100 \mathrm{nM}$ para $150 \mathrm{nM}$}

As primeiras tipagens foram realizadas de acordo com as condições descritas por Martin ${ }^{(37)}$. Como o padrão de bandas do controle interno foi muito fraco, diferentes concentrações do par de iniciadores que amplificava o controle interno foram testadas: $150 \mathrm{nM}, 180 \mathrm{nM}$ e $200 \mathrm{nM}$ (dados não mostrados). A menor concentração com melhor resultado foi de $150 \mathrm{nM}$. Dessa forma, a concentração dos iniciadores do controle interno foi alterada de $100 \mathrm{nM}$ para $150 \mathrm{nM}$ (Figura 1).

\section{Alteração da concentração de iniciadores específicos de $500 \mathrm{nM}$ para $750 \mathrm{nM}$}

Os segundos pares dos iniciadores que amplificam os genes KIR2DL4, KIR2DS2, KIR3DS1 e KIR3DL3 apresentaram padrão de banda com menor intensidade (Figura 2). Por isso foi alterada a concentração do segundo par de iniciadores específicos KIR8.5/8.3 (2DL4), KIR12.5/12.3 (2DS2), KIR22.5/22.3 (3DS1), KIR36.5/36.6 (3DL3). O melhor resultado foi obtido quando a concentração final dos iniciadores específicos KIR12.5/12.3, KIR22.5/22.3 e KIR36.5/36.6 foi aumentada de $500 \mathrm{nM}$ para $750 \mathrm{nM}$ (Figura 3). A concentração final do segundo par de iniciadores (KIR8.5/8.3) que amplifica KIR2DL4 foi mantida em $500 \mathrm{nM}$.

Para o gene KIR2DS3 foram realizados testes com as concentrações finais de $500 \mathrm{nM} \mathrm{e} 750 \mathrm{nM}$ para os dois pares 
Tabela 1 Sequência dos iniciadores utilizados para genotipagem KIR por PCR-SSP

\begin{tabular}{|c|c|c|c|c|c|}
\hline Gene & Iniciador & Sequências & Éxon & Posição & Tamanho \\
\hline 2DL1 & $\begin{array}{l}\text { KIR1.5/1.3A } \\
\text { KIR2.5/2.3A }\end{array}$ & $\begin{array}{l}\text { GTT GGT CAG ATG TCA TGT TTG AA } \\
\text { GGT CCC TGC CAG GTC TTG CG } \\
\text { TGG ACC AAG AGT CTG CAG GA } \\
\text { TGT TGT CTC CCT AGA AGA CG }\end{array}$ & $\begin{array}{l}4 \\
4 \\
8 \\
9\end{array}$ & $\begin{array}{c}472-494 \\
598-617 \\
1159-1178 \\
1403-1422\end{array}$ & $\begin{array}{r}146 \\
\sim 330\end{array}$ \\
\hline 2DL2 & $\begin{array}{l}\text { KIR3.5/3.3 } \\
\text { KIRex5.5/5.3 }\end{array}$ & $\begin{array}{l}\text { CTG GCC CAC CCA GGT CG } \\
\text { GGA CCG ATG GAG AAG TTG GCT } \\
\text { GAG GGG GAG GCC CAT GAA T } \\
\text { TCG AGT TTG ACC ACT CGT AT }\end{array}$ & $\begin{array}{l}4 \\
4 \\
5 \\
5\end{array}$ & $\begin{array}{l}419-435 \\
571-591 \\
813-831 \\
944-963\end{array}$ & $\begin{array}{l}173 \\
150\end{array}$ \\
\hline 2DL3 & $\begin{array}{l}\text { KIR5.5/5.3 } \\
\text { KIR6.5/6.3 }\end{array}$ & $\begin{array}{l}\text { CTT CAT CGC TGG TGC TG } \\
\text { AGG CTC TTG GTC CAT TAC AA } \\
\text { TCC TTC ATC GCT GGT GCT G } \\
\text { GGC AGG AGA CAA CTT TGG ATC A }\end{array}$ & $\begin{array}{l}7 \\
8 \\
7 \\
9\end{array}$ & $\begin{array}{l}1118-1134 \\
1153-1172 \\
1116-1134 \\
1350-1371\end{array}$ & $\begin{array}{l}\sim 550 \\
\sim 800\end{array}$ \\
\hline 2DL4 & $\begin{array}{l}\text { KIR7.5/7.3 } \\
\text { KIR8.5/8.3 }\end{array}$ & $\begin{array}{l}\text { CAG GAC AAG CCC TTC TGC } \\
\text { CTG GGT GCC GAC CAC T } \\
\text { ACC TTC GCT TAC AGC CCG } \\
\text { GGG TTT CCT GTG ACA GAA ACA G }\end{array}$ & $\begin{array}{l}3 \\
3 \\
5 \\
5\end{array}$ & $\begin{array}{l}116-133 \\
354-369 \\
709-727 \\
975-996\end{array}$ & $\begin{array}{l}254 \\
288\end{array}$ \\
\hline 2DS2 & $\begin{array}{l}\text { KIR11.5/11.3 } \\
\text { KIR12.5/12.3 }\end{array}$ & $\begin{array}{l}\text { TTC TGC ACA GAG AGG GGA AGT A } \\
\text { AGG TCA CTG GGA GCT GAC AA } \\
\text { CGG GCC CCA CGG TTT } \\
\text { GGT CAC TCG AGT TTG ACC ACT CA }\end{array}$ & $\begin{array}{l}4 \\
4 \\
5 \\
5\end{array}$ & $\begin{array}{l}501-522 \\
656-675 \\
729-743 \\
946-968\end{array}$ & $\begin{array}{l}173 \\
240\end{array}$ \\
\hline 2DS3 & $\begin{array}{l}\text { KIR13.5/13.3 } \\
\text { KIR14.5/14.3 }\end{array}$ & $\begin{array}{l}\text { TGG CCC ACC CAG GTC G } \\
\text { TGA AAA CTG ATA GGG GGA GTG AGG } \\
\text { CTA TGA CAT GTA CCA TCT ATC CAC } \\
\text { AAG CAG TGG GTC ACT TGA C }\end{array}$ & $\begin{array}{l}4 \\
4 \\
5 \\
5\end{array}$ & $\begin{array}{l}420-435 \\
638-661 \\
787-810 \\
958-976\end{array}$ & $\begin{array}{l}242 \\
190\end{array}$ \\
\hline 2DS4 & $\begin{array}{l}\text { 9Fa/12Ra } \\
\text { del.5B } \\
\text { del.3 }\end{array}$ & $\begin{array}{l}\text { CTG GCC CTC CCA GGT CA TCT GTA } \\
\text { GGT TCC TGC AAG GAC AG } \\
\text { GTT CAG GCA GGA GAG AAT } \\
\text { GTT TGA CCA CTC GTA GGG AGC }\end{array}$ & $\begin{array}{l}4 \\
4\end{array}$ & $\begin{array}{l}416-435 \\
600-622\end{array}$ & $\begin{array}{c}204 \\
197 / 219\end{array}$ \\
\hline 2DS5 & $13 F / 9 R$ & $\begin{array}{l}\text { TGA TGG GGT CTC CAA GGG } \\
\text { TCC AGA GGG TCA CTG GGC }\end{array}$ & $\begin{array}{l}4 \\
4\end{array}$ & $\begin{array}{l}557-574 \\
665-682\end{array}$ & 125 \\
\hline 2DS1 & $\mathrm{F} 1 / \mathrm{F} 2 / \mathrm{R} 3$ & $\begin{array}{l}\text { CTTCTCCATCAGTCGCATGAA } \\
\text { CTTCTCCATCAGTCGCATGAG } \\
\text { AGAGGGTCACTGGGAGCTGAC }\end{array}$ & $\begin{array}{l}4 \\
4 \\
4\end{array}$ & $\begin{array}{l}578-598 \\
578-598 \\
659-679\end{array}$ & 102 \\
\hline 3DL1 & $\begin{array}{l}\text { 7Fa/3Ra } \\
\text { 3DS1..5a/13Ra }\end{array}$ & $\begin{array}{l}\text { CGC TGT GGT GCC TCG A } \\
\text { GGT GTG AAC CCC GAC ATG } \\
\text { CCC TGG TGA AAT CAG GAG AGA G } \\
\text { TGT AGG TCC CTG CAA GGG CAA }\end{array}$ & $\begin{array}{l}3 \\
3 \\
4 \\
4\end{array}$ & $\begin{array}{l}144-163 \\
321-340 \\
435-456 \\
600-620\end{array}$ & $\begin{array}{l}197 \\
181\end{array}$ \\
\hline 3DL2 & $\begin{array}{l}\text { KIR19.5/19.3 } \\
\text { KIR20.5/20.3 }\end{array}$ & $\begin{array}{l}\text { CAA ACC CTT CCT GTC TGC CC } \\
\text { GTG CCG ACC ACC CAG TGA } \\
\text { CCC ATG AAC GTA GGC TCC G } \\
\text { CAC ACG CAG GGC AGG G }\end{array}$ & $\begin{array}{l}3 \\
3 \\
5 \\
5\end{array}$ & $\begin{array}{l}121-140 \\
348-365 \\
822-840 \\
936-951\end{array}$ & $\begin{array}{l}245 \\
130\end{array}$ \\
\hline 3DS1 & $\begin{array}{l}\text { Ex9.1/9.3 } \\
\text { KIR22.5/22.3 }\end{array}$ & $\begin{array}{l}\text { AGC CTG CAG GGA ACA GAA G } \\
\text { GCC TGA CTG TGG TGC TCG } \\
\text { CCT GGT GAA ATC AGG AGA GAG } \\
\text { GTC CCT GCA AGG GCA C }\end{array}$ & $\begin{array}{l}8 \\
9 \\
4 \\
4\end{array}$ & $\begin{array}{c}1169-1189 \\
1377-1394 \\
436-456 \\
600-615\end{array}$ & $\begin{array}{l}\sim 300 \\
177\end{array}$ \\
\hline
\end{tabular}


Tabela 1 Sequência dos iniciadores utilizados para genotipagem KIR por PCR-SSP (cont.)

\begin{tabular}{|c|c|c|c|c|c|}
\hline Gene & Iniciador & Sequências & Éxon & Posição & Tamanho \\
\hline 3DL3 & KIR35.5/35.3 & $\begin{array}{l}\text { GTC AGA TGT CAG GTT TGA GCG } \\
\text { CAT GGA ATA GTT GAC CTG GGA AC } \\
\text { GCA GCT CCC GGA GCT TG } \\
\text { GGG TCT GAC CAC GCG TG }\end{array}$ & $\begin{array}{l}4 \\
4 \\
5 \\
5\end{array}$ & $\begin{array}{l}467-487 \\
556-578 \\
763-779 \\
936-952\end{array}$ & 190 \\
\hline 2DL5 & KIR29.5/29.3 & $\begin{array}{l}\text { GCG CTG TGG TGC CTC G } \\
\text { GAC CAC TCA ATG GGG GAG C } \\
\text { TGC AGC TCC AGG AGC TCA } \\
\text { GGG TCT GAC CAC TCA TAG GGT }\end{array}$ & $\begin{array}{l}3 \\
3 \\
5 \\
5\end{array}$ & $\begin{array}{l}148-163 \\
343-361 \\
771-788 \\
941-961\end{array}$ & $\begin{array}{l}214 \\
194\end{array}$ \\
\hline 2DP1 & KIR33.5/33.3 & $\begin{array}{l}\text { GTC TGC CTG GCC CAG CT } \\
\text { GTG TGA ACC CCG ACA TCT GTA C } \\
\text { CCA TCG GTC CCA TGA TGG } \\
\text { CAC TGG GAG CTG ACA ACT GAT G }\end{array}$ & $\begin{array}{l}3 \\
3 \\
4 \\
4\end{array}$ & $\begin{array}{l}134-150 \\
317-338 \\
583-600 \\
651-672\end{array}$ & $\begin{array}{r}205 \\
90\end{array}$ \\
\hline CONTROLE & IC $5^{\prime} /$ IC $3^{\prime}$ & $\begin{array}{l}\text { TGC CAA GTG GAG CAC CCA A } \\
\text { GCA TCT TGC TCT GTG CAG AT }\end{array}$ & & & 796 \\
\hline
\end{tabular}

Fonte: $\operatorname{Martin}^{(37)}$

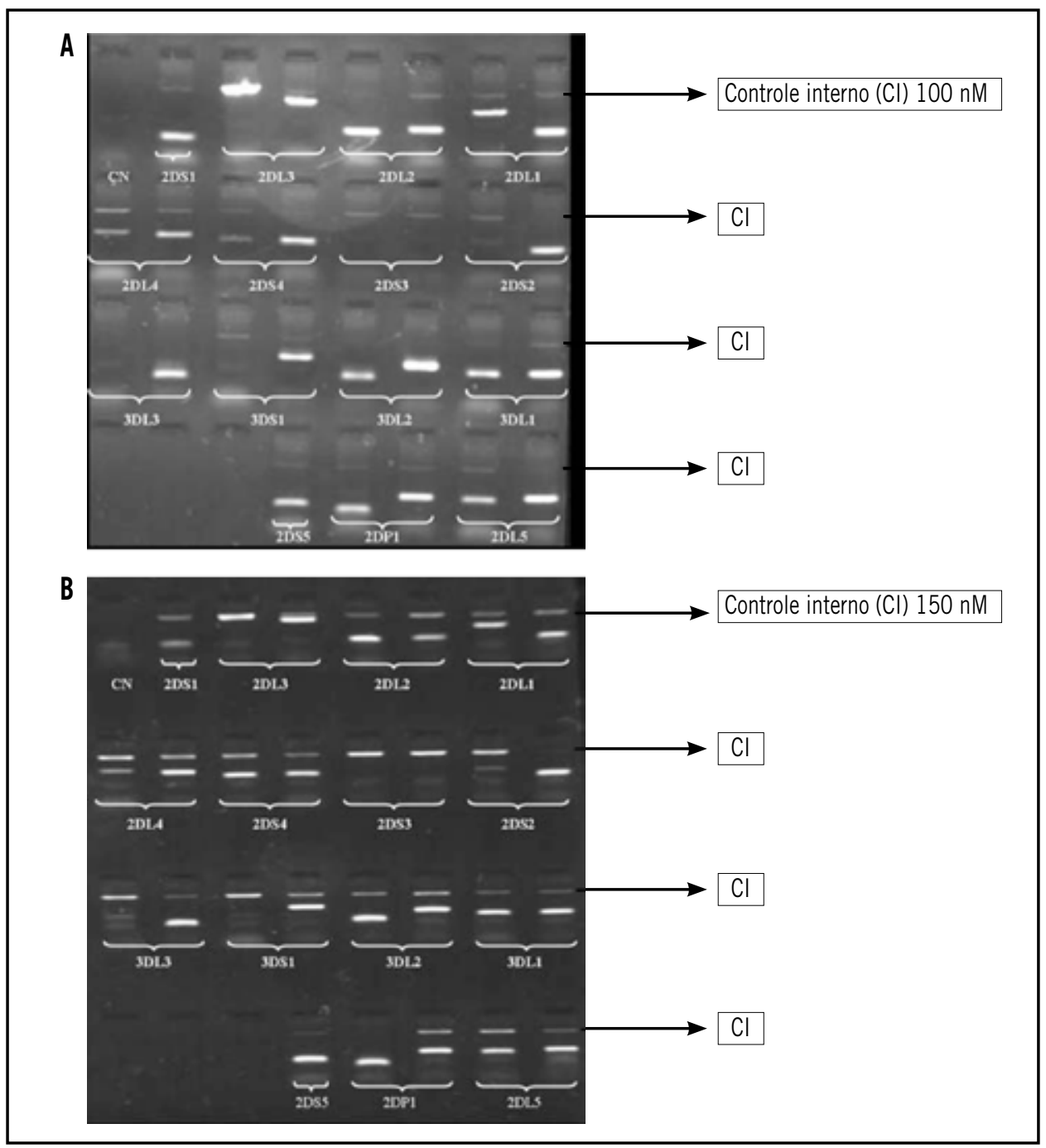

Figura 1 - Fotodocumentação de genotipagem KIR. Concentração final dos iniciadores do controle interno: 100 nM (A) e 150 nM (B) $\mathrm{CN}$ : controle negativo. 


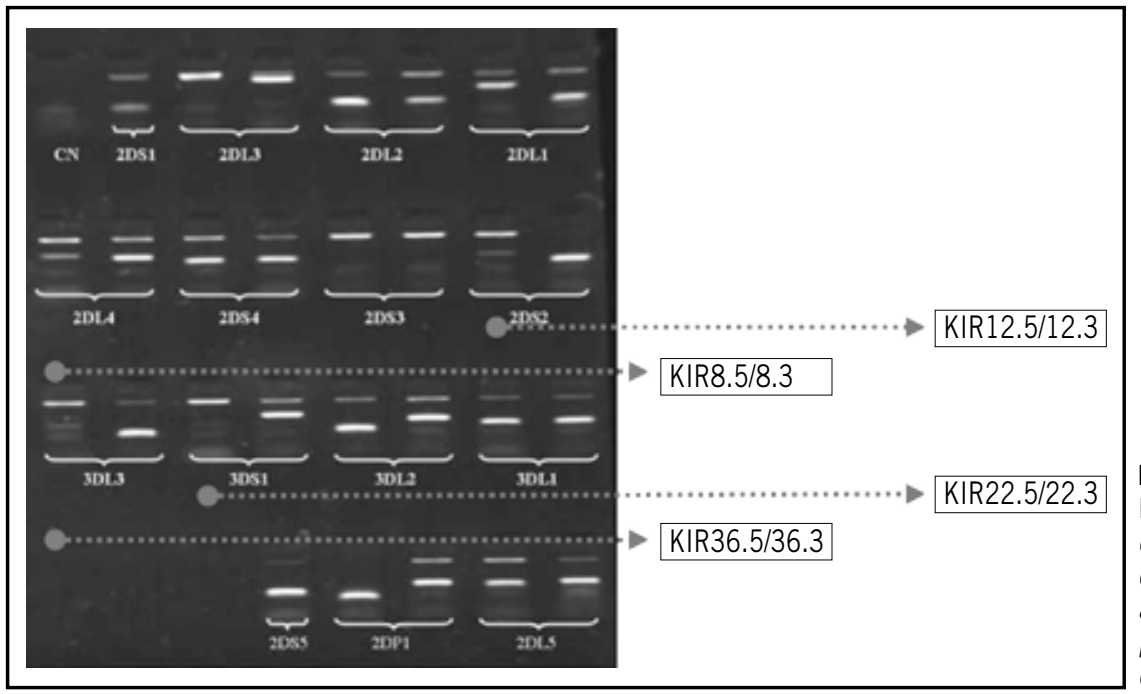

Figura 2 - Padrão de bandas dos genes KIR2DL4, KIR2DS2, KIR3DS1 e KIR3DL3 com iniciadores específicos na concentração de $500 \mathrm{nM}$. 0 primeiro e o segundo par de iniciadores localizam-se à direita e à esquerda, respectivamente. Observar que o segundo par de iniciadores destes genes apresentaram padrão de banda de menor intensidade em relação aos demais

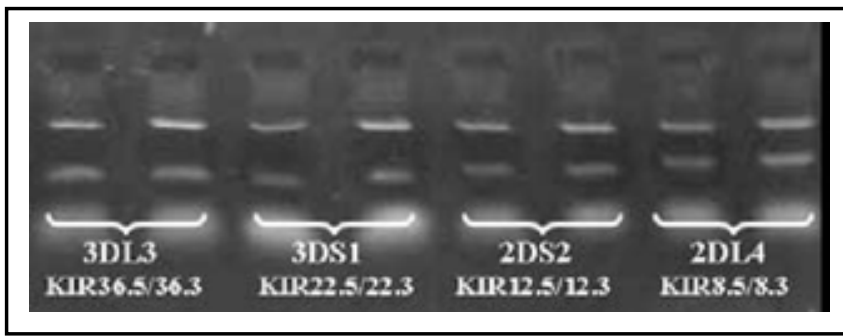

de iniciadores: KIR13.5/13.3 e KIR14.5/14.3. Para ambos, os melhores resultados foram obtidos na concentração final de $750 \mathrm{nM}$.

\section{Alteração na concentração de cloreto de magnésio $\left(\mathrm{MgCl}_{2}\right)$ de 1,5 $\mathrm{mM}$ para $2 \mathrm{mM}$}

Como o padrão de banda dos genes KIR2DS2, KIR3DS1 e KIR3DL3 continuava fraco, mesmo após aumento na concentração do segundo par dos iniciadores KIR12.5/12.3 (2DS2), KIR22.5/22.3 (3DS1) e KIR36.5/36.6 (3DL3) para $750 \mathrm{nM}$, uma modificação na concentração de $\mathrm{MgCl}_{2}$ foi realizada. A alteração da concentração de $1,5 \mathrm{mM}$ para $2 \mathrm{mM}$ contribuiu para a obtenção de melhores resultados (Figura 4).

\section{Verificação da ocorrência de reações inespecíficas}

Na PCR, o cloreto de magnésio atua como cofator para a enzima Taq DNA polimerase e sua presença é indispensável; no entanto, em excesso, pode provocar reações inespecíficas $^{(44)}$. Em nosso experimento, o desenvolvimento da PCR usando solução de $\mathrm{MgCl}_{2}$ a $2 \mathrm{mM}$ (acima da recomendada
Figura 3 - Padrão de bandas dos genes KIR2DL4, KIR2DS2, KIR3DS1 e KIR3DL3. 0 segundo par dos iniciadores especificos KIR8.5/8.3 (2DL4), KIR12.5/12.3 (2DS2), KIR22.5/22.3 (3DS1) e KIR36.5/36.6 (3DL3) foi testado na concentração de $750 \mathrm{nM}$. 0 teste foi realizado em duplicata

pelo protocolo original, ou seja, 1,5 mM) não provocou a formação de reações inespecíficas, conforme apresentado na Figura 6.

\section{Uso da enzima Taq DNA polimerase recombinante}

De acordo com o protocolo padrão, melhores resultados são obtidos com o uso da enzima Platinum ${ }^{\circledast}$ Taq DNA polimerase. No entanto, a enzima Taq DNA polimerase recombinante (Invitrogen ${ }^{\circledR}$, Carlsbad, CA, EUA) mostrou eficiência na PCR para tipagem de genes KIR. Os resultados são apresentados na Figura 5.

\section{Condições finais da reação}

As condições finais da PCR para a tipagem de genes KIR adequadas às nossas condições laboratoriais são descritas a seguir: para $10 \mu \mathrm{l}$ de reação foram utilizados de tampão PCR 10X - 200 mM Tris-HCl (pH 8,4) e 500 mM KCl; 2 mM de $\mathrm{MgCl}_{2 ;} 200 \mu \mathrm{M}$ de cada desorribonuleotídeo trifosfatado (dNTP); $150 \mathrm{nM}$ de iniciadores $5^{\prime}$ e $3^{\prime}$ do controle interno; $750 \mathrm{nM}$ dos iniciadores específicos KIR12.5/12.3 (2DS2), KIR13.5/13.3 e KIR14.5/14.3 (2DS3), KIR22.5/22.3 (3DS1), 


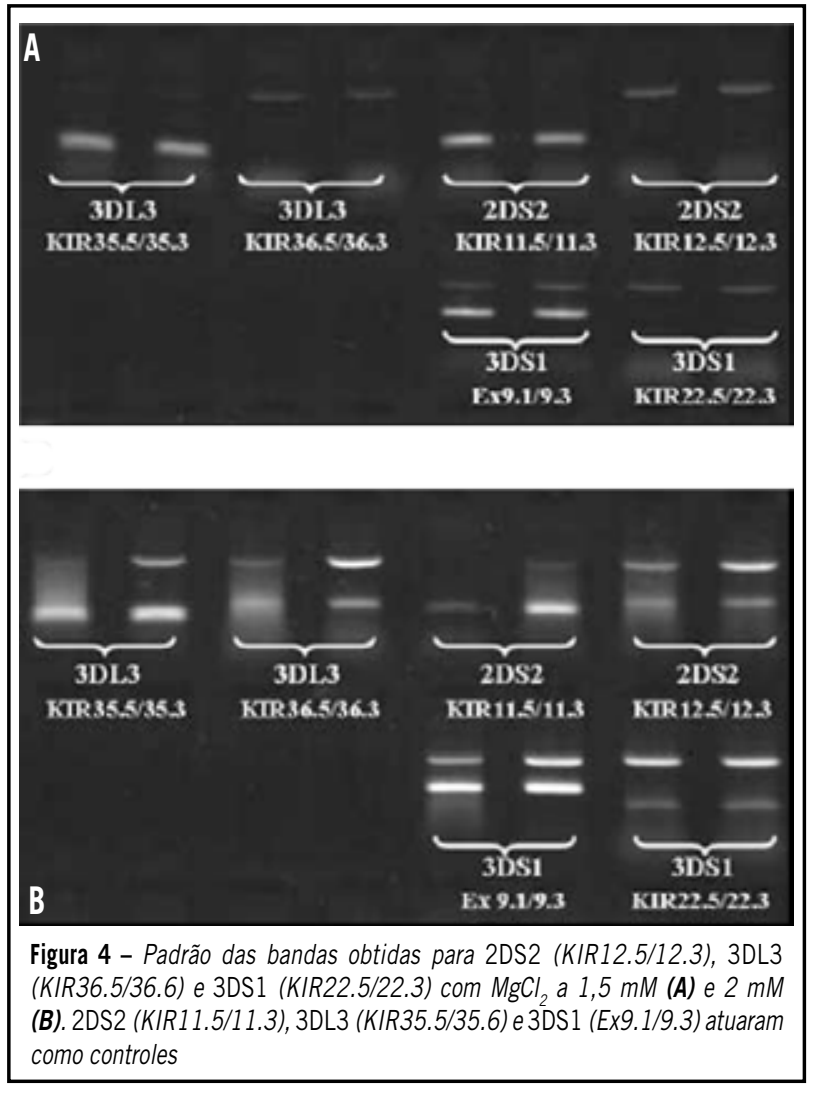

KIR36.5/36.6 (3DL3) e $500 \mathrm{nM}$ para os demais; 0,25 unidade de Platinum Taq DNA polimerase (Invitrogen ${ }^{\circledR}$, Carlsbad, CA, EUA) ou Taq DNA polimerase recombinante (Invitrogen ${ }^{\circledR}$, Carlsbad, CA, EUA); aproximadamente $10 \mathrm{ng}$ de DNA e água destilada estéril suficiente para completar $10 \mu \mathrm{l}$. As temperaturas e condições de amplificação foram mantidas.

\section{Validação do método}

As 70 amostras genotipadas por PCR-SSP foram analisadas pelo kit de genotipagem rSSO (One Lambda, Canoga Park, EUA), tecnologia Luminex ${ }^{\circledast}$. Três amostras apresentaram resultados divergentes em apenas um gene KIR, sendo duas amostras para KIR2DS5 e uma para KIR2DL1, e essas diferenças se mantiveram após a repetição por ambas as técnicas.

Uma amostra genotipada como positiva para o gene KIR2DS5 e outra como positiva para o gene KIR2DL1, pelo método PCR-SSP otimizado, foram genotipadas como negativas pelo método rSSO Luminex ${ }^{\circledR}$, enquanto, uma amostra genotipada como negativa para o gene KIR2DS5 pelo método PCR-SSP otimizado foi positiva pelo rSSO Luminex.

No entanto, quando essas amostras foram avaliadas pelo kit comercial de genotipagem KIR SSP (DYNAL ${ }^{\circledast}$ Invitrogen Corporation, lote 003), para confirmação dos resultados,

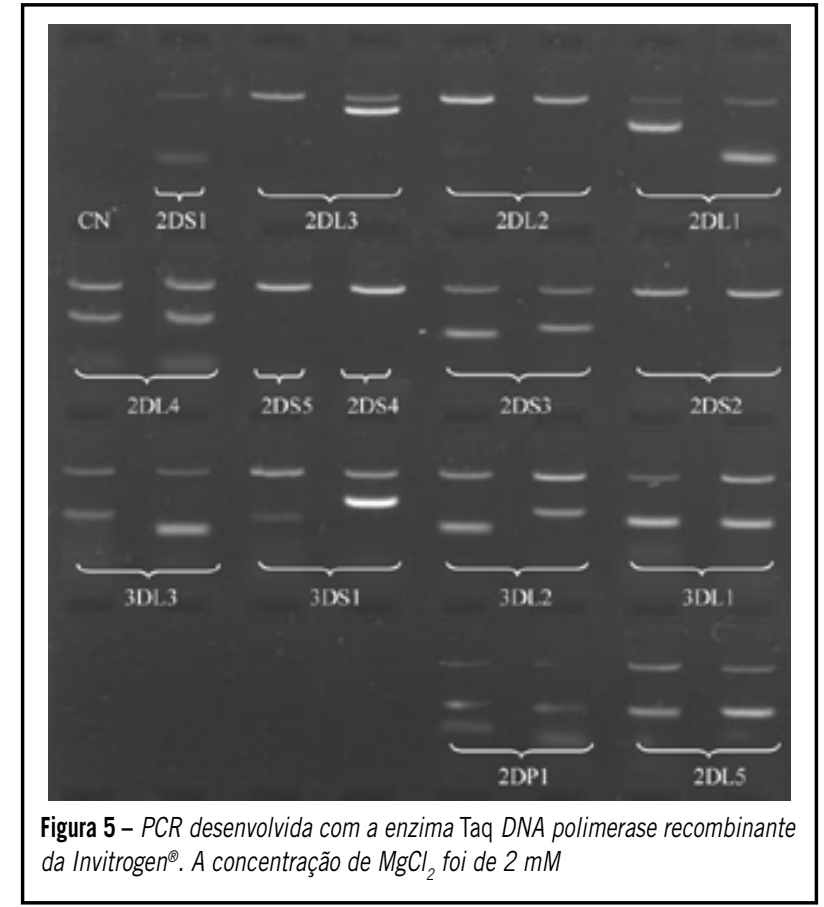

houve concordância com todos os resultados referentes às reações da PCR-SSP otimizada.

\section{Discussão}

A partir da genotipagem KIR descrita por Uhrberg et al.(53), vários grupos desenvolveram metodologias para a tipagem destes genes ${ }^{(9,19,34,41,51)}$, de forma a obter um aprimoramento na identificação dos genes e permitir a definição dos alelos.

Os métodos utilizados para detectar a presença ou ausência de genes KIR se baseiam em técnicas de biologia molecular. Pela técnica RT-PCR, Uhrberg et al.(53) verificaram que a combinação de genes KIR em humanos é altamente polimórfica, levando à expressão de diferentes fenótipos. No mesmo estudo, eles desenvolveram a metodologia PCR-SSP para identificar 12 genes KIR a partir do DNA genômico, obtido de células mononucleares do sangue periférico.

Crum et al.(9) utilizaram a técnica molecular PCR-SSOP para tipagem de 12 genes KIR, com base na amplificação de três diferentes regiões: os domínios extracelulares do tipo imunoglobulina proximal e distal à membrana e os domínios transmembranal-citoplasmático, seguida da hibridização com sondas de sequência específica marcadas com digoxigenina. Por esta técnica também conseguiram distinguir dois alelos de KIR3DL1.

Em 2002, Gómez-Lozano e Vilches ${ }^{(19)}$ identificaram genes e pseudogenes recém-descritos KIR2DL5, KIR3DL3, 
KIR3DP1 e KIR2DP1 e as variantes de KIR2DL5, utilizando a técnica PCR-SSP.

A genotipagem KIR pela técnica PCR-SSP, utilizando iniciadores que fornecem pequenos amplicons (108-565 pb), foi descrita por Sun et al. ${ }^{(51)}$ e aprimorada por Martin ${ }^{(37)}$. Essa técnica apresentou como vantagens a economia no custo de reagentes e de mão de obra qualificada e a obtenção de bons resultados com DNA parcialmente degradado.

A técnica rSSO com tecnologia Lumine ${ }^{\circledR}$ para tipagem dos genes e alelos KIR foi descrita por Nong et al. ${ }^{(41)}$. Essa técnica apresenta como vantagens a determinação de alelos nulos não identificados por métodos convencionais e permite a análise de várias amostras em um sistema múltiplo. No entanto, o custo é elevado quando comparado com as outras técnicas.

Neste estudo, a proposta foi a otimização de uma metodologia de genotipagem KIR por PCR-SSP, de baixo custo, fácil execução, reprodutível e confiável, utilizando iniciadores sintetizados. A metodologia foi baseada na PCR-SSP descrita por Martin( ${ }^{(37)}$, que permitiu a detecção de 14 genes KIR e um pseudogene, o KIR2DP1. O produto de amplificação foi um pequeno fragmento em sua maioria, de 90 a 200 pb; dois produtos apresentaram aproximadamente 300 pb, um 550 pb e outro com 800 pb. Todos os produtos foram facilmente identificados e definidos em gel de agarose.

Para a confiabilidade das reações foi utilizado um controle interno para cada reação que amplifica o terceiro íntron do gene HLA-DRB1, cujo produto é um fragmento de 796 pb. O uso do controle interno na PCR determina se a ausência de amplificação específica é realmente devida à ausência do gene na amostra de DNA, e não à falha de amplificação de $P C R^{(12)}$. Devido a diferentes concentrações e temperaturas de hibridização dos iniciadores específicos comparados com os iniciadores do controle interno, a intensidade da banda do controle geralmente foi menos intensa quando ocorreu amplificação específica ${ }^{(12,19)}$.

Para confirmar a presença ou ausência de um determinado gene foram realizadas duas reações com diferentes pares de iniciadores, os quais amplificavam diferentes éxons de um mesmo gene, exceto para KIR2DS1 e KIR2DS5, com reação única.

A análise envolveu 15 genes em 70 indivíduos não relacionados pela técnica PCR-SSP otimizada e por rSSO sistema Luminex ${ }^{\circledR}$, totalizando 1.050 tipagens. Do total das amostras avaliadas, foram observados resultados divergentes para três genes, sendo um para o gene KIR2DL1 e outros dois para o gene KIR2DS5 $(0,29 \% ; p=0,2478)$.
Esses resultados se mantiveram conflitantes após repetição das genotipagens por ambas as metodologias.

Em função desses resultados conflitantes, foi utilizada uma terceira metodologia, que usa o kit comercial de genotipagem KIR SSP (DYNAL ${ }^{\circledR}$ Invitrogen Corporation, lote 003) para genotipar essas amostras. Os resultados foram concordantes com aqueles obtidos na PCR-SSP otimizada e, consequentemente, discordantes do método rSSO comercial Luminex ${ }^{\circledR}$. Dessa forma podemos observar que todos os resultados obtidos na PCR-SSP otimizada foram confirmados por uma ou outra técnica comercial.

Podem existir algumas explicações para essas divergências, como a especificidade dos primers e sondas utilizados nas técnicas de SSO e SSP, os quais podem se ligar a regiões diferentes dos genes KIR2DS5 e KIR2DL1; a utilização de um único primer e sonda para identificar o gene KIR2DS5, pela ausência de outra sequência capaz de identificá-lo; problemas técnicos, como a reduzida ou aumentada sensibilidade dos primers usados, resultando em falsos positivos ou falsos negativos ou a caracterização de variantes alélicas. O sequenciamento genômico é a única maneira de averiguar esses achados.

Interessantemente, resultados divergentes também foram observados em uma caracterização multilaboratorial (três laboratórios) de genotipagem KIR para o Décimo Workshop Internacional de Histocompatibilidade ${ }^{(7)}$. Do total de 25 linhagens celulares, três apresentaram divergências para esses mesmos genes, KIR2DL1 e KIR2DS5, quando genotipadas pelas técnicas de PCR-SSP e PCR-SSOP.

Esses resultados poderiam sugerir que a tipagem para esses particulares genes KIR devem ser observadas com cautela e que futuros estudos são necessários para resolver esse fato, o que pode incluir a construção de primers e sondas mais específicos.

Uma das vantagens dessa técnica foi relacionada com a concentração de DNA, ou seja, 10 ng em cada reação. No entanto, a qualidade e a concentração de DNA são pontos críticos da reação. Outras vantagens foram o baixo custo, pois utiliza pouca quantidade de reagentes (volume final da reação foi de $10 \mu \mathrm{l}$ ), e a possibilidade de ser desenvolvida em laboratório de biologia molecular sem a exigência de equipamentos sofisticados. Além disso, a enzima Platinum Taq DNA polimerase (Invitrogen ${ }^{\circledR}$, Carlsbad, CA, EUA) pôde ser substituída pela Taq DNA polimerase recombinante (Invitrogen ${ }^{\circledR}$, Carlsbad, CA, EUA), de menor custo.

Finalmente, essa técnica mostrou sensibilidade, especificidade, reprodutibilidade e que pode ser de fácil execução para a maioria dos laboratórios de biologia molecular. 


\section{Conclusão}

A metodologia PCR-SSP otimizada neste estudo pode ser utilizada por laboratórios de biologia molecular em diversos estudos de genotipagem KIR, a qual se mostrou sensível, específica, reprodutível, de fácil execução e baixo custo.

\section{Agradecimentos}

Os autores agradecem aos voluntários que participaram deste estudo e ao Dr. Eduardo José Melo dos Santos e à Dra. Luiza Tamie Tsuneto pelas sugestões e críticas na leitura do manuscrito.

\section{Referências}

1. BECKER, S. etal. Assessment of killer cell immunoglobulinlike receptor expression and corresponding HLA class I phenotypes demonstrates heterogenous KIR expression independent of anticipated HLA class I ligands. Hum Immunol, v. 64, n. 2, p. 183-93, 2003.

2. BERAN, M.; HANSSON, M.; KIESSLING, R. Human natural killer cells can inhibit clonogenic growth of fresh leukemic cells. Blood, v. 61, n. 3, p. 596-9, 1983.

3. BESSON, C. et al. Association of killer cell immunoglobulinlike receptor genes with Hodgkin's Lymphoma in a familial study. PLoSONE, v. 2, n. 5, e406, p. 1-10, 2007.

4. BIRON, C.A. Activation and function of natural killer cell responses during viral infections. Curr Opin Immunol, v. 9, n. 1, p. 24-34, 1997.

5. BONTADINI, A. etal. Distribution of killer cell immunoglobulinlike receptors genes in the Italian Caucasian population. J Trans/ Med, v. 4, 44, 2006.

6. COLONNA, M. et al. Generation of allospecific natural killer cells by stimulation across a polymorphism of HLA-C. Science, v. 260, n. 5111, p.1121-24, 1993.

7. COOK, M. A. et al. A multi-laboratory characterization of the KIR genotypes of $10^{\text {th }}$ international histocompatibility workshop cell lines. Hum Immunol, v. 64, n. 5, p. 567-71, 2003.

8. COOK, M. A.; MOSS, P. A. H.; BRIGGS, D. C. The distribution of 13 killer-cell immunoglobulin-like receptor loci in UK blood donors from three ethnic groups. Eur $\mathrm{J}$ Immunogenet, v. 30, n. 3, p. 213-21, 2003.

9. CRUM, K. A. et al. Development of a PCR-SSOP approach capable of defining the natural killer cell inhibitory receptor (KIR) gene sequence repertoires. Tissue Antigens, v. 56, n. 4, p. 313-26, 2000.

10. DE OLIVEIRA, D. C. M. et al. Identificação dos genótipos KIR na população brasileira. Rev Bras Hematol Hemoter, v. 28, Suppl. 1, p. 22-34, 2006.

11. DENIS, L. et al. Genetic diversity of KIR natural killer cell markers in populations from France, Guadeloupe, Finland, Senegal and Réunion. Tissue Antigens, v. 66, n. 4, p. 267-76, 2005.

12. DYNAL. Tissue typing Dynal-SSP. Technical handbook. 1. ed. Norway, 1996. 63 p.

13. EWERTON, P. D. et al. Amazonian Amerindians exhibit high variability of KIR profiles. Immunogenetics, v. 59, n. 8, p. 625-30, 2007.

14. FLORES, A. C. et al. KIR genes polymorphism in Argentinean Caucasoid and Amerindian populations. Tissue Antigens, v. 69, n. 6, p. 568-76, 2007.
15. FLORES-VILLANUEVA, P. O. et al. Control of HIV-1 viremia and protection from AIDS are associated with HLA-Bw4 homozygosity. Proc Natl Acad Sci USA, v. 98, n. 9, p. 5140-5, 2001.

16. FRASSATI, C. et al. Distribution of killer-cell immunoglobulinlike receptor (KIR) in Comoros and Southeast France. Tissue Antigens, v. 67, n. 5, p. 356-67, 2006.

17. GARCIA, C.A. et al. Human KIR sequences 2003. Immunogenetics, v. 55, n. 4, p.227-39, 2003.

18. GENDZEKHADZE, K. et al. High KIR diversity in Amerindians is maintained using few gene-content haplotypes. Immunogenetics, v. 58, n. 5-6, p. 474-80, 2006.

19. GÓMEZ-LOZANO, N. et al. Some human KIR haplotypes contain two KIR2DL5 genes: KIR2DL5A and KIR2DL5B. Immunogenetics, v. 54, n. 5, p. 314-9, 2002.

20. GÓMEZ-LOZANO, N.; VILCHES, C. Genotyping of human killer-cell immunoglobulin-like receptor genes by polymerase chain reaction with sequence-specific primers: an update. Tissue Antigens, v. 59, n. 3, p. 184-93, 2002.

21. GUTIÉRREZ-RODRÍGUEZ, M. E. et al. KIR gene in ethnic and mestizo populations from Mexico. Hum Immunol, v. 67, n. 1-2, p. 85-93, 2006.

22. HAYAKAWA, Y.; SMYTH, M. J. Innate immune recognition and suppression of tumors. Adv Cancer Res, v. 95, p.293-322, 2006.

23. HERCEND, T. et al. Characterization of natural killer cells with antileukemia activity following allogeneic bone marrow transplantation. Blood, v. 67, n. 3, p. 722-8, 1986.

24. HSU, K.C. et al. Killer lg-like receptor haplotype analysis by gene content: evidence for genomic diversity with a minimum of six basic framework haplotypes, each with multiple subsets. J Immunol, v. 169, n. 9, p. 5118-29, 2002.

25. IPD-KIR DATABASE. Disponível em: <http://www.ebi.ac.uk/ $\mathrm{ipd} / \mathrm{kir} / \mathrm{stats}$.html>. Acesso em: 29 out. 2009.

26. JENNES, W. et al. Cutting edge: resistance to HIV-1 infection among African female sex workers is associated with inhibitory KIR in the absence of their HLA ligands. J Immunol, v. 177, n. 10, p. 6588-92, 2006.

27. JIANG, K. et al. Distribution of killer cell immunoglobulinlike receptor genes in the Chinese Han population. Tissue Antigens, v. 65, n. 6, p. 556-63, 2005.

28. JONES, D. C. et al. Killer Ig-like receptor (KIR) genotype and HLA ligand combinations in ulcerative colitis 
susceptibility. Genes Immun, v. 7, n. 7, p. 576-82, 2006.

29. KÄRRE, K. NK cells, MHC class I molecules and missing self. Scand J Immunol, v. 55, n. 3, p. 221-8, 2002.

30. KHAKOO, S. I. et al. HLA and NK cell inhibitory receptor genes in resolving Hepatitis $\mathrm{C}$ virus infection. Science, v. 305, n. 5685, p. 872-4, 2004.

31. LANIER, L. L. NK cell receptors. Annu Rev Immunol, v.16, p. 359-93, 1998.

32. LÓPEZ-VÁZQUEZ, A. et al. Interaction between KIR3DL1 and HLA-B*57 supertype alleles influences the progression of HIV-1 infection in a Zambian population. Hum Immunol, v. 66, n. 3, p. 285-9, 2005.

33. LUSZCZEK, W. et al. Inhibitory and activatory KIR gene frequencies in the Polish population. Int J Immunogenet, v. 33, n. 3, p. 167-70, 2006.

34. MAHFOUZ, R. et al. Distribution of killer cell immunoglobulin-like receptors genotypes in the Lebanese population. Tissue Antigens, v. 68, n. 1, p. 66-71, 2006.

35. MARSH, S. G. E. et al. Killer-cell immunoglobulinlike receptor (KIR) nomenclature report, 2002. Immunogenetics, v. 55, n. 4, p. 220-6, 2003.

36. MARTIN, M. P. etal. Epistatic interaction between KIR3DS1 and HLA-B delays the progression to AIDS. Nat Genet, v. 31, n. 4, p. 429-34, 2002.

37. MARTIN, M. P. Tipagem de genes KIR e sua aplicação em estudos de populações, associação com doenças e transplantes. In: VIII CONGRESSO DA SOCIEDADE BRASILEIRA DE TRANSPLANTE DE MEDULA ÓSSEA, 2004, Curitiba.

38. MAXWELL, L. D. et al. Investigation of KIR diversity in immunosenecence and longevity within the Irish population. Exp Gerontol, v. 39, n. 8, p. 1223-32, 2004.

39. MORETTA, A. et al. Existence of both inhibitory ( $p 58$ ) and activatory ( $p 50)$ receptors for HLA-C molecules in human natural killer cells. J Exp Med, v. 182, n. 3, p. 875-84, 1995.

40. NIOKOU, D. et al. Distribution of killer cell immunoglobulinlike receptors in the Greek population. Hum Immunol, v. 64 , n. 12 , p. 1167-76, 2003.

41. NONG, T. et al. KIR genotyping by reverse sequencespecific oligonucleotide methodology. Tissue Antigens, v. 69, Suppl. 1, p. 92-5, 2007.

42. NORMAN, P. J. et al. Distribution of natural killer cell immunoglobulin-like receptor sequences in three ethnic groups. Immunogenetics, v. 52, n. 3-4, p. 195-205, 2001.

43. NORMAN, P. J. et al. Natural killer cell immunoglobulin-like receptor (KIR) locus profiles in African and South Asian populations. Genes Immun, v. 3, n. 2, p. 86-95, 2002.

44. PROMEGA. PCR core systems. Technical bulletin. N. 254 USA, 2001. 20 p.

45. RAJALINGAM, R. et al. Distinctive KIR and HLA diversity in a panel of north Indian Hindus. Immunogenetics, v. 53, n. 12, p. 1009-19, 2002.

46. RAJALINGAM, R. et al. Identification of seventeen novel KIR variants: fourteen of them from two non-Caucasian donors. Tissue Antigens, v. 57, n. 1, p. 22-31, 2001.
47. RUDNICK, C. C. et al. Killer cell immunoglobulin-like receptor gene diversity in a Southern Brazilian population from the state of Paraná. Hum Immunol, v. 69, n. 12, p. 872-6, 2008.

48. RUGGERI, L. et al. Role of natural killer cell alloreactivity in HLA-mismatched hematopoietic stem cell transplantation. Blood, v. 94, n. 1, p. 333-39, 1999.

49. SANTIN, I. et al. Killer cell immunoglobulin-like receptor $(K I R)$ genes in the Basque population: association study of KIR gene contents with type I Diabetes Mellitus. Hum Immunol, v. 67, n. 1-2, p. 118-24, 2006.

50. SHILLING, H. G. et al. Allelic polymorphism synergizes with variable gene content to individualize human KIR genotype. J Immunol, v. 168, n. 5, p. 2307-15, 2002.

51. SUN, J.Y. et al. Development of a multiplex PCR-SSP method for killer-cell immunoglobulin-like receptor genotyping. Tissue Antigens, v. 64, n. 4, p. 462-68, 2004.

52. TONEVA, M. et al. Genomic diversity of natural killer cell receptor genes in three populations. Tissue Antigens, v. 57, n. 4, p. 358-62, 2001.

53. UHRBERG, M. et al. Human diversity in killer cell inhibitory receptor genes. Immunity, v. 7, n. 6, p. 753-63, 1997.

54. VELICKOVIC, M.; VELICKOVIC, Z.; DUNCKLEY, H. Diversity of killer cell immunoglobulin-like receptor genes in Pacific Islands populations. Immunogenetics, v. 58, n. 7, p. 523-32, 2006.

55. WHANG, D. H. et al. Haplotype analysis of killer cell immunoglobulin-like receptor genes in 77 Korean families. Hum Immunol, v. 66, n. 2, p. 146-154, 2005.

56. WILSON, M. J. et al. Plasticity in the organization and sequences of human KIR/ILT gene families. Proc Natl Acad Sci USA, v. 97, n. 9, p. 4778-83, 2000.

57. WITT, C. S. et al. Population frequencies and putative haplotypes of the killer cell immunoglobulin-like receptor sequences and evidence for recombination. Transplantation, v. 68, n. 11, p. 1784-89, 1999.

58. YANG, Q. et al. Antitumor activity of NK cells. Immunol Res, v. 36, n. 1-3, p. 13-25, 2006.

59. YAWATA, M. et al. Predominance of group A KIR haplotypes in Japanese associated with diverse NK cell repertoires of KIR expression. Immunogenetics, v. 54, n. 8, p. 543-50, 2002. 